\title{
Hubungan Antara Citra Tubuh Dengan Perilaku Konsumtif Pada Remaja Di Kota Banda Aceh
}

\section{Correlation Between Body Image and Consumptive Behavior On Adolescents In Banda Aceh}

\author{
Rahmi Rizky ${ }^{1} \&$ Risana Rachmatan ${ }^{2}$ \\ Program Studi Psikologi Fakultas Kedokteran Universitas Syiah Kuala \\ Jl. Teuku Nyak Arief Darussalam Banda Aceh. Aceh 23111 \\ mikyto43@gmail.com; risanarachmatan@unsyiah.ac.id
}

\begin{abstract}
KATA KUNCI citra tubuh, perilaku konsumtif, remaja, Banda Aceh
KEYWORDS body image, consumptive behaviour, adolescents, Banda Aceh
\end{abstract}

ABSTRAK Berbagai perubahan yang dialami pada masa remaja menyebabkan remaja menjadi sangat memperhatikan citra tubuh mereka dan melakukan berbagai upaya untuk meningkatkan penampilannya. Salah satu upaya remaja dalam meningkatkan penampilan adalah dengan melakukan perilaku konsumtif. Penelitian ini bertujuan untuk mengetahui hubungan antara citra tubuh dengan perilaku konsumtif pada remaja di Kota Banda Aceh. Teknik pengambilan sampel yang digunakan adalah kuota sampling dengan jumlah sampel sebanyak 300 remaja yang diambil sesuai dengan ciri-ciri tertentu hingga mencapai jumlah yang dibutuhkan. Terdapat dua alat ukur yang digunakan, yaitu Kuesioner Multidimensional Body Self Relations Questionnaire - Appearance Scale (MBSRQ-AS) yang mengacu pada teori Cash (2002) terdiri dari 34 aitem dan Skala Perilaku Konsumtif disusun oleh peneliti mengacu pada teori Lina dan Rosyid (dalam Petova, 2012) terdiri dari 17 aitem. Hasil analisis data menggunakan teknik korelasi Pearson menunjukkan koefisien korelasi (r) sebesar 0,032 dengan nilai $p=0,002(p<0,05)$. Berdasarkan hasil tersebut maka hipotesis yang diajukan diterima. Hasil penelitian menunjukkan hubungan positif dan signifikan antara citra tubuh dengan perilaku konsumtif pada remaja di Kota Banda Aceh, hasil ini berbeda dengan beberapa hasil penelitian sebelumnya yang menunjukkan hubungan negatif.

ABSTRACT The various changes in experience of adolescents causes them more concern about their body image and make them effortful to improve their appearance. One of that, adolescents are improved their appearance by performing consumptive behavior. This study aimed to determine the correlation between body image and consumptive behavior on adolescents in Banda Aceh. The sampling technique was quota sampling with 300 samples who were taken in accordance with certain characteristics to achieve required number. 
The measuring instruments were Multidimensional Body Self Relations Questionnaire - Appearance Scale (MBSRQ-AS) based on Cash's theory (2002) consisted of 34 items and Consumptive Behaviour Scale based on the theory of Lina and Rosyid (in Petova, 2012) consisting of 17 items. The results of the data analysis using Pearson correlation technique showed a coefficient correlation $(r)=0,032$ with $p=0,002(p<0.05)$. The results showed that there was positive and significant relationship between body image with the consumptive behavior on adolescents in Banda Aceh. The result tends to show different result from previous studies which used the same variable.

\section{PENDAHULUAN}

Masa remaja merupakan suatu periode transisi perkembangan antara masa kanak-kanak dengan masa dewasa. Periode transisi ini melibatkan terjadinya perubahan-perubahan secara biologis, kognitif dan sosio-emosional (Santrock, 2007). Perubahan pada masa remaja secara biologis dapat terlihat dengan terjadinya perubahan pada fisik, kemudian perubahan secara kognitif dapat terlihat dari perubahan dalam pola pikir dan perubahan secara sosioemosional yang merupakan perubahan yang berhubungan dengan individu lain dapat terlihat dalam interaksi dan dalam kepribadian individu disuatu masyarakat (Rombe, 2014). Perubahan biologis meliputi perubahan fisik individu yang ditandai dengan pubertas.

Pubertas merupakan awal penting yang menandai awal mula masa remaja. McCabe dan Ricciardelli (dalam Santrock, 2007) menjelaskan bahwa salah satu aspek psikologis dari pubertas yang paling sering muncul pada laki-laki dan perempuan adalah praokupasi (perhatian yang berlebihan) remaja terhadap tubuhnya. Perhatian tersebut membuat remaja mulai berfikir untuk melakukan perubahan pada bentuk tubuh, hal ini berlangsung pada usia 15 tahun (Papalia, Olds \& Feldman, 2008). Praokupasi terhadap citra tubuh cukup kuat pada masa remaja dan secara khusus kecenderungan tersebut menjadi akut pada masa pubertas (Santrock, 2007). Menurut Rombe (2014) salah satu dampak psikologis dari perubahan tubuh pada saat masa pubertas terhadap remaja adalah adanya perasaan cemas dengan tubuh mereka sehingga membentuk citra tubuh mengenai kondisi tubuh mereka.

Schilder (dalam Grogan, 2008) mendefinisikan citra tubuh sebagai gambaran bagaimana tubuh individu terlihat, gambaran tubuh individu tersebut terbentuk dari dalam pikiran individu. Menurut Sari dan Siregar (2012) citra tubuh merupakan evaluasi atau sikap yang dimiliki seseorang secara partisipatif terhadap tubuhnya. Evaluasi atau sikap tersebut bisa berupa perasaan suka, puas atau positif yang ditunjukkan dengan penerimaan terhadap tubuhnya atau bisa berupa perasaan tidak suka, tidak puas atau negatif seseorang terhadap atribut fisik pada tubuhnya seperti ukuran tubuh, berat badan dan bentuk tubuh.

Menurut Januar dan Putri (2007) apa yang individu pikirkan dan rasakan, belum tentu benar-benar mempresentasikan keadaan yang sebenarnya, hal tersebut merupakan hasil penilaian diri yang bersifat subjektif. Terdapat beberapa faktor penting yang dapat mempengaruhi penilaian terhadap citra tubuh pada 
individu seperti sosialisasi budaya, pengalaman interpersonal (bersama teman sebaya, pasangan, keluarga dan orang sekitar), karakteristik fisik dan sifat kepribadian (Cash, 2008). Selain itu, menurut Januar dan Putri (2007) penilaian terhadap citra tubuh juga dipengaruhi oleh faktor lainnya, seperti tayangan dan tampilan media massa yang menampilkan bentuk tubuh ideal sehingga menimbulkan kecenderungan remaja untuk membandingkan bentuk tubuhnya dengan bentuk tubuh remaja seusianya.

$$
\text { Stang dan Story (2005) }
$$

menjelaskan bahwa terdapat banyak remaja yang awalnya tidak dapat menerima keadaan fisik mereka yang baru berkembang. Hal ini diungkapkan dalam penelitiannya yang dilakukan pada remaja di Amerika, dimana terdapat $50 \%$ sampai $88 \%$ remaja merasa tidak puas dengan bentuk dan ukuran tubuhnya. Hanya $33 \%$ remaja yang mengatakan bahwa tubuhnya bagus, sementara $58 \%$ remaja ingin menurunkan berat badannya dan $9 \%$ remaja lainnya ingin menaikkan berat badan. Menurut Melliana (2006) fenomena citra tubuh negatif yang terjadi di Barat juga terjadi di Indonesia karena adanya pengaruh media massa yang menggambarkan standar untuk tubuh ideal. Berdasarkan penelitian, terdapat 22\% remaja di Banda Aceh merasa tidak puas dengan citra tubuhnya dan beberapa diantaranya masih ragu-rugu antara puas atau tidak puas terhadap citra tubuh yang dimiliki (Ristia, 2014).

Media massa memiliki pengaruh yang besar dalam membangun kognisi masyarakat, terutama yang berkaitan dengan citra tubuh (Bestiana, 2012). Banyaknya media yang menampilkan figur-figur remaja serta produk-produk remaja dan adanya ketidakpuasan terhadap kondisi tubuhnya mempengaruhi remaja untuk menjadi konsumtif pada penampilannya, sehingga mereka semakin boros dalam pengeluaran uang sakunya demi mendapatkan penampilan yang menurut mereka ideal (Rombe, 2014).

Reynold (dalam Sumartono, 2002) mengatakan remaja membelanjakan uangnya lebih banyak untuk menunjang penampilan diri sehingga perilaku konsumtif di kalangan remaja terbilang tinggi. Hal ini dikarenakan remaja mudah tertarik dan terbujuk pada barang dan jasa yang sedang trend (Sebayang, Yusuf \& Priyatama, 2011). Selain itu, perilaku konsumtif juga dominan dikalangan remaja karena secara psikologis remaja masih berada dalam proses pencarian jati diri dan sangat sensitif terhadap pengaruh luar atau lingkungan (Sumartono, 2002). Fromm (1976) menyebutkan bahwa perilaku konsumtif adalah perilaku mengkonsumsi barang secara kompulsif dan tidak rasional, yang tidak didasarkan pada kebutuhan melainkan keinginan dan dilakukan demi menjaga penampilan diri dan meningkatkan status sosial serta gengsi.

Hasil penelitian dibeberapa kota besar di Indonesia menunjukkan adanya perilaku konsumtif pada remaja. Hasil penelitian yang dilakukan oleh Ambarwati dan Safitri (2011) menunjukkan bahwa $60 \%$ remaja di Yogyakarta memiliki perilaku konsumtif. Selanjutnya penelitian oleh Gumulya dan Widiastuti (2013) menunjukkan bahwa 48,9\% remaja di Jakarta memiliki perilaku konsumtif. Sementara itu, penelitian oleh Sari (2009) menunjukkan bahwa 64,64\% remaja di Medan memiliki perilaku konsumtif. Salah satu penelitian yang memperlihatkan adanya hubungan negatif antara citra tubuh dan perilaku konsumtif pada remaja SMA adalah penelitian yang dilakukan oleh Rombe 
(2014) di Samarinda. Penelitian tersebut menunjukkan apabila citra tubuh yang dimiliki remaja putri positif maka perilaku konsumtif remaja tersebut akan rendah, begitu pula sebaliknya apabila citra tubuh remaja putri negatif maka perilaku konsumtif remaja akan tinggi. Penelitian ini bertujuan untuk mengetahui hubungan antara citra tubuh dengan perilaku konsumtif pada remaja di Kota Banda Aceh.

\section{METODE PENELITIAN}

Penelitian ini merupakan penelitian kuantitatif dengan jenis penelitian korelasi. Penelitian korelasi adalah penelitian untuk mengetahui hubungan dan tingkat hubungan antara dua variabel atau lebih tanpa ada upaya untuk mempengaruhi variabel tersebut sehingga tidak terdapat manipulasi variabel (Sugiyono, 2013). Adapun populasi penelitian ini adalah seluruh remaja yang ada di Kota Banda Aceh. Teknik pengambilan sampel untuk menentukan jumlah sampel yaitu menggunakan quota sampling. Teknik quota sampling merupakan teknik untuk menentukan sampel dari populasi yang mempunyai ciri-ciri tertentu sampai jumlah kuota yang diinginkan (Sugiyono, 2013). Penggunaan quota sampling dilakukan karena tidak diketahui jumlah remaja yang berusia 15 sampai 20 tahun di Kota Banda Aceh secara pasti sehingga peneliti menentukan sampel penelitian berdasarkan kuota yaitu 300 orang. Teknik ini dianggap dapat mewakili seluruh remaja di Kota Banda Aceh. Adapun criteria sampel penelitian adalah : a) Berdomisili di Kota Banda Aceh, b) Berusia 15 hingga 20 tahun, c) Bersedia menjadi responden penelitian.

\section{Metode pengumpulan data}

Metode pengumpulan data yang digunakan adalah skala psikologi, yaitu
Kuesioner MBSRQ-AS dan Skala Perilaku Konsumtif. Citra tubuh dalam penelitian ini diukur dengan menggunakan kuesioner baku Multidimensional Body Self Relations Questionnaire - Appearance Scale (MBSRQ-AS) yang sudah diadaptasi berdasarkan 5 sub-komponen yang disusun oleh Cash (Collings, 2005), yaitu: evaluasi penampilan (appearance evaluation), orientasi terhadap penampilan (appearance orientation), kecemasan terhadap kegemukan (overweight preoccupation), pengkategorian ukuran tubuh (selfclassified weight) dan kepuasan terhadap bagian tubuh (body areas satisfaction scale). Kuesioner terdiri dari 34 aitem dengan menggunakan skala model likert yang terdiri dari 5 jawaban (respon). Sedangkan Skala Perilaku Konsumtif dirancang dan disusun oleh peneliti dengan menggunakan aspek perilaku konsumtif yang dikemukakan oleh Lina dan Rosyid (dalam Petova, 2012), yaitu pembelian impulsif, pembelian tidak rasional, pembelian boros atau berlebihan. Skala Perilaku Konsumtif terdiri dari 17 aitem dengan menggunakan skala model likert yang terdiri dari 4 jawaban (respon).

\section{Metode analisis data}

Data yang diperoleh dari penelitian dianalisis menggunakan teknik korelasi Pearson dengan menggunakan program SPSS Versi 18.0 for Windows.

\section{ANALISIS DAN HASIL Deskripsi subjek penelitian}

Berdasarkan data demografi sampel penelitian yang diperoleh dari hasil penelitian dapat dilihat pada tabel 1. 
Tabel 1. Data Demografi Sampel Penelitian

\begin{tabular}{cccccc}
\hline No. & Deskripsi Sampel & Kategori & Jumlah & Persentase & Total \\
\hline 1 & Jenis Kelamin & Laki-laki & 96 & $32 \%$ & $100 \%$ \\
& & Perempuan & 204 & $68 \%$ & \\
\hline 2. & Usia & 15 & 50 & $16,6 \%$ & $100 \%$ \\
& 16 & 50 & $16,7 \%$ & \\
& 17 & 50 & $16,7 \%$ & \\
& & 18 & 50 & $16,7 \%$ & \\
& & 19 & 50 & $16,7 \%$ & \\
& & 20 & $16,6 \%$ & \\
\hline 3. & Jenjang Pendidikan & SMA/Sederajat & 176 & $58,7 \%$ & $100 \%$ \\
& & Perguruan Tinggi & 124 & $41,3 \%$ & \\
\hline
\end{tabular}

Berdasarkan tabel diatas dapat dilihat bahwa jumlah sampel penelitian yang berjenis kelamin perempuan lebih besar daripada jumlah sampel laki-laki, yaitu sebesar $68 \%$ sedangkan jumlah sampel penelitian yang berjenis kelamin laki-laki yaitu sebesar 32\%. Sampel penelitian dibagikan kedalam 6 kategori usia yaitu, usia 15 sampai dengan 20 tahun dimana masing-masing usia terdiri dari 50 sampel penelitian. Berdasarkan tabel di atas juga dapat dilihat sampel dengan jenjang pendidikan sebagai siswa lebih besar daripada mahasiswa, yaitu sebesar $58,7 \%$ sedangkan jumlah sampel mahasiswa yaitu sebesar $41,3 \%$.

\section{Uji asumsi}

\section{Uji normalitas}

Hasil uji normalitas yang dilakukan pada 300 sampel penelitian menunjukkan pada variabel citra tubuh diperoleh hasil K-S Z $=1,031 p=0,238$ $>0,05$ artinya variabel tersebut berdistribusi normal dengan $(p>0,05)$. Selanjutnya, hasil uji normalitas pada variabel perilaku konsumtif diperoleh nilai $\mathrm{K}-\mathrm{S}, \mathrm{Z}=1,262 p=0,083>0,05$ yang artinya variabel tersebut juga berdistribusi normal dengan $(p>0,05)$.

\section{Uji linieritas}

Hasil uji linearitas yang dilakukan dari 300 sampel penelitian melalui ANOVA test for linearity menunjukkan nilai signifikansi pada linearitas sebesar 0,001. Nilai signifikansi 0,001 tersebut merupakan nilai yang kurang dari $0,05(p=0,001<$ 0,05). Hal tersebut memperlihatkan hubungan yang linear antara variabel citra tubuh dengan variabel perilaku konsumtif.

\section{Uji hipotesis}

Uji hipotesis dilakukan dengan menggunakan analisis korelasi Product Moment Correlation Pearson dikarenakan kedua data variabel penelitian ini berdistribusi normal dan linier. Metode ini digunakan untuk menganalisis hubungan antara citra tubuh dengan perilaku konsumtif pada remaja di Kota Banda Aceh. Hasil analisis menunjukkan nilai signifikansi $p=0,002(p<0,05)$. Hal tersebut menunjukkan bahwa hipotesis penelitian ini diterima yaitu ada hubungan antara citra tubuh dengan perilaku konsumtif pada remaja di Kota Banda Aceh.

Hasil analisis penelitian menunjukkan koefisien korelasi sebesar 0,178 yaitu korelasi positif yang artinya terdapat hubungan yang positif antara citra tubuh dengan perilaku konsumtif. Hubungan tersebut mengartikan bahwa semakin tinggi citra tubuh maka semakin tinggi pula perilaku konsumtif pada remaja di Kota Banda Aceh.

Selain itu, hasil analisis pada penelitian ini juga menunjukkan sumbangan efektif dari kedua variabel yang dilihat dari analisis measures of 
association. Hasil analisis tersebut menunjukkan nilai $R$ Square $\left(\mathrm{R}^{2}\right)=$ 0,032 yang artinya terdapat $3,2 \%$ pengaruh citra tubuh terhadap perilaku konsumtif, sementara 96,8\% dipengaruhi oleh faktor-faktor lain.

\section{Deskripsi data citra tubuh dan perilaku konsumtif}

Gambaran umum mengenai data penelitian variabel citra tubuh dan perilaku konsumtif dapat dilihat pada tabel 2

Tabel 2. Deskripsi Data Penelitian Variabel Citra Tubuh dan Perilaku Konsumtif

\begin{tabular}{ccccccccc}
\hline \multirow{2}{*}{ Variabel } & \multicolumn{3}{c}{ Data Hipotetik } & \multicolumn{5}{c}{ Data Empirik } \\
\cline { 2 - 9 } & Xmaks & Xmin & Mean & SD & Xmaks & Xmin & Mean & SD \\
\hline Citra Tubuh & 23 & 5,5 & 14,25 & 2,91 & 22,2 & 11,2 & 15,9 & 2 \\
\hline $\begin{array}{c}\text { Perilaku } \\
\text { Konsumtif }\end{array}$ & 68 & 17 & 42,5 & 8,5 & 67 & 19 & 36,6 & 7,6 \\
\hline
\end{tabular}

Berdasarkan hasil statistik data penelitian, analisis deskriptif secara hipotetik menunjukkan bahwa jawaban minimal pada variabel citra tubuh adalah 5,5, maksimal 23, nilai rerata 14,25 , dan simpangan baku 2,91. Kategorisasi ini membagi skor subjek ke dalam dua kategori yaitu skor tinggi untuk citra tubuh yang positif dan skor rendah untuk citra tubuh yang negatif berdasarkan teori Cash. Kategorisasi ini menggunakan nilai mean atau nilai ratarata sebagai nilai batas kategori. Skor yang lebih besar daripada mean didiagnosis sebagai positif sedangkan skor yang berada di bawah mean didiagnosis negatif (Danisya, 2012). Adapun kategorisasi dapat dilihat pada tabel 3.

Tabel 3. Kategorisasi Citra Tubuh

\begin{tabular}{cccc}
\hline Skor & Kategori & Jumlah & Persentase \\
\hline $\mathrm{X}<15,9$ & Negatif & 130 & $43,3 \%$ \\
$15,9 \leq \mathrm{X}$ & Positif & 170 & $56,7 \%$ \\
\hline
\end{tabular}

Sementara itu, hasil statistik data penelitian, analisis deskriptif secara hipotetik menunjukkan bahwa jawaban minimal pada variabel perilaku konsumtif adalah 17 , maksimal 68 , nilai rerata 42,5, dan simpangan baku 8,5. Data deskriptif di atas dapat digunakan untuk membagi pengkategorian sampel penelitian yang terdiri dari tiga kategori, yaitu rendah, sedang dan tinggi. Pembagian kategori sampel yang digunakan peneliti adalah kategorisasi berdasar model distribusi normal dengan kategorisasi jenjang (ordinal). Menurut Azwar (2013) kategorisasi jenjang (ordinal) merupakan kategorisasi yang menempatkan individu kedalam kelompok-kelompok yang posisinya berjenjang menurut suatu kontinum berdasakan atribut yang diukur.

\section{DISKUSI}

Hasil penelitian menunjukkan bahwa terdapat hubungan yang positif dan signifikan antara citra tubuh dengan perilaku konsumtif pada remaja di Kota Banda Aceh. Hal tersebut dibuktikan dengan hasil perhitungan statistik dari nilai koefisien korelasi $r_{x y}=0,178$ dan nilai signifikansi sebesar 0,002 ( $p<$ $0,05)$, sehingga dapat dikatakan bahwa hipotesis penelitian ini diterima.

Hasil penelitian berbeda dengan beberapa penelitian sebelumnya, namun sejalan dengan penelitian yang dilakukan oleh Murasmutia, Hardjajani dan Adi (2015) pada mahasiswi Fakultas Hukum Universitas Sebelas Maret Surakarta yang menemukan 
bahwa terdapat hubungan yang signifikan antara citra tubuh dengan perilaku konsumtif. Penelitian tersebut menjelaskan bahwa individu yang memiliki citra tubuh yang positif berarti puas atau senang dengan bentuk tubuh dan penampilan fisiknya, didukung dengan kepercayaan diri yang tinggi maka akan meningkatkan perilaku konsumtif. Penelitian tersebut juga menegaskan bahwa individu yang memiliki citra tubuh yang positif cenderung memiliki tingkat perilaku konsumtif terhadap pakaian yang tinggi.

Berdasarkan hasil penelitian, sebanyak 56,7\% (170 orang) remaja di Kota Banda Aceh memiliki citra tubuh yang positif. Citra tubuh yang positif dapat membantu individu untuk merasa bangga dan menghargai tubuhnya (Tylka \& Barcalow, 2014). Citra tubuh yang positif tersebut dapat disebabkan oleh beberapa faktor, diantaranya adalah sosialisasi budaya, pengalaman interpersonal, karakteristik fisik dan sifat kepribadian (Cash, 2008). Pengalaman interpersonal remaja dengan orang tua, saudara kandung dan juga teman sebayanya mempengaruhi sikap remaja terhadap penampilannya melalu komentar-komentar, candaan dan modeling yang diberikan (Nanu, Taut \& Baban, 2014). Kepuasan dan ketidakpuasan remaja di Kota Banda Aceh terhadap penampilan keseluruhannya tidak dapat dipisahkan dari pengaruh karakteristik fisik, sifat kepribadian dan sosialisasi budaya yang ada di Aceh. Hal ini sesuai dengan penelitian yang dilakukan oleh Wahyuni (2013) yang menjelaskan bahwa salah satu budaya, adat istiadat dan aturan di daerah Aceh yang sesuai dengan ajaran syariat Islam yaitu berpakaian yang menutupi aurat mempengaruhi perkembangan citra tubuh para remaja di Kota Banda Aceh. Remaja Banda Aceh yang pada umumnya berpakaian menutup aurat secara tidak langsung lebih diuntungkan karena dapat menutupi bagian-bagian tubuh yang tidak disukai sehingga mereka merasa lebih puas terhadap penampilan, hal ini mempengaruhi perkembangan citra tubuh remaja.

Menjelaskan lebih lanjut mengenai hasil penelitian dimana sebagian besar remaja memiliki citra tubuh yang positif dapat merujuk pada Stuard dan Laraia (2005) yang mengemukakan bahwa citra tubuh merupakan sesuatu yang dinamis. Hal ini dikarenakan citra tubuh dapat berubah secara kontinu seiring dengan adanya pengalaman dan persepsi baru. Pernyataan yang sama juga dinyatakan Waller dan Barner (2002) dimana citra tubuh dapat menjadi sebuah konstruk yang dinamis yang bergantung pada faktor sosial dan psikologis individu.

Hasil penelitian juga menunjukkan bahwa 59,7\% (179 remaja) di Kota Banda Aceh memiliki perilaku konsumtif yang sedang. Hasil ini berarti secara umum remaja di Kota Banda Aceh memiliki tingkat perilaku konsumtif yang tergolong sedang. Menurut Anggreini dan Mariyanti (2014) individu yang memiliki perilaku konsumtif yang tinggi adalah individu yang membeli karena emosi sesaat bukan karena kebutuhannya. Oleh karena itu, individu-individu dengan perilaku konsumtif yang sedang dan rendah dapat mengendalikan aktivitas membelinya sehingga sesuai dengan kebutuhan.

Perilaku konsumtif yang sedang dapat dipengaruhi oleh berbagai faktor yaitu, kepuasan diri, harga diri, kepercayaan diri dan status sosial (Enrico, 2014). Selain faktor tersebut Lina dan Rasyid (dalam Imawati, 2013) menambahkan bahwa perilaku konsumtif seseorang juga dapat dipengaruhi oleh kebudayaan, kelas 
sosial, keluarga, pengamatan, motivasi dan sikap. Faktor-faktor tersebut saling mempengaruhi individu untuk melakukan perilaku konsumtif. Perilaku konsumtif remaja di Kota Banda Aceh yang berada pada kategori sedang terjadi karena subjek penelitian lebih di dominasi oleh siswa SMA/Sederajat yang masih belum memiliki pendapatan sendiri. Semakin tinggi pendapatan yang diterima individu dari berbagai sumber (seperti: uang saku), menyebabkan individu semakin mempunyai keinginan untuk membeli apa yang diinginkan melebihi apa yang dibutuhkan (Harli, Linawati \& Memarista, 2015). Hal ini sejalan dengan penelitian sebelumnya terkait dengan perilaku konsumtif yang dilakukan oleh Fachrunnizza (2015) yang menjelaskan bahwa tinggi atau rendahnya perilaku konsumtif dapat dipengaruhi oleh pekerjaan dan penghasilan perbulan individu. Kontribusi citra tubuh terhadap perilaku konsumtif remaja di Kota Banda Aceh sebesar 3,2\%, dimana hal ini menunjukkan bahwa terdapat 96,8\% faktor lainnya seperti konformitas, harga diri dan kepercayaan diri dapat mempengaruhi perilaku konsumtif remaja.

\section{SIMPULAN}

Hasil penelitian ini menunjukkan bahwa terdapat hubungan positif antara citra tubuh dengan perilaku konsumtif pada remaja di Kota Banda Aceh. Hubungan positif mengindikasikan bahwa semakin positif citra tubuh maka semakin tinggi juga perilaku konsumtif. Selanjutnya, hasil penelitian ini menunjukkan bahwa umumnya remaja di Kota Banda Aceh memiliki citra tubuh positif dan perilaku konsumtif remaja di Kota Banda Aceh mayoritas berada pada kategori sedang. Individu dengan citra tubuh yang positif akan mampu mengendalikan perilaku konsumtif dengan baik.

\section{SARAN}

Berdasarkan hasil penelitian ini, maka terdapat beberapa saran dari peneliti diantaranya adalah:

\section{Kepada remaja di Kota Banda Aceh}

Bagi remaja di Kota Banda Aceh yang sudah memiliki citra tubuh yang positif diharapkan dapat mempertahankan citra tubuhnya tersebut dan perilaku konsumtif yang berada pada tingkatan sedang ini tetap dipertahankan dan semakin dikurangi. Remaja juga diharapkan dapat memanfaatkan uang dengan bijaksana dan lebih selektif dalam membeli sehingga membeli tidak hanya untuk dapat tampil menarik di depan umum.

\section{Kepada peneliti selanjutnya}

Dianjurkan bagi peneliti selanjutnya yang tertarik untuk meneliti citra tubuh dengan perilaku konsumtif pada remaja di Kota Banda Aceh untuk dapat mempertimbangkan variabel lain yang mungkin dapat mempengaruhi perilaku konsumtif seperti harga diri, kepercayaan diri dan kelompok sebaya. Variabel tersebut penting untuk diteliti karena perilaku konsumtif merupakan suatu fenomena yang akan terus berkembang dan menjadi hal yang tidak dapat dipisahkan dari kehidupan seharihari.

\section{DAFTAR PUSTAKA}

Ambarwati, Y., \& Safitri, R.M. (2011). Hubungan antara kepribadian narsistik dengan perilaku konsumtif pada remaja di Yogyakarta. Jurnal Psikologi, 2(2), 53-101.

Anggreini, R., \& Mariyanti, S. (2014). Hubungan antara control diri dengan perilaku konsumtif mahasiswa Universitas Esa Unggul. Jurnal Psikologi, 12(1), 34-42. 
Azwar, S. (2013). Penyusunan skala psikologi. Yogyakarta: Pustaka Pelajar.

Azwar, S. (2013). Reliabilitas dan validitas. Yogyakarta: Pustaka Pelajar.

Bestiana, D. (2012). Citra tubuh dan konsep tubuh ideal mahasiswi FISIP Universitas Airlangga Surabaya. Jurnal AntroUnairDotNet, 1(1), 111.

Cash, T, F. (2008). The body image work book: an eight step for learning to your looks (Ed. 2). New Harbinger Publication: United States of America.

Cash, T.F., \& Pruzinsky, T. (2002). Body image: a handbook of theory, research, and clinical practice. New York: The Guilford Press.

Collings, A. S. (2005). The relationship between body image and weight maintenance in community women enrolled in weight-loss programs. Masters's theses and doctoral dissertations. Eastern Michigan University, Michigan.

Danisya. (2012). Hubungan antara citra tubuh dengan kebiasaan makan pada remaja putri di SMA Negeri 28 Jakarta. Skripsi. Universitas Indonesia, Jakarta.

Enrico, A., Aron, R., \& Oktavia, W. (2014). The factor that influenced consumptive behavior: a survey of university student in Jakarta. International Journal of Scientific and Research Publictions, 4(1), 1-6.

Fachrunnizza, I. (2015). Hubungan konsep diri dengan perilaku konsumtif pada pria metroseksual di Banda Aceh. Skripsi. Universitas Syiah Kuala, Banda Aceh.

Fromm, E. (1976). To have to be. New York: Continuum London.

Grogan, S. (2008). Body image: understanding body dissatisfaction in men, women, and children. New York: Psychology Press.

Gumulya, J., \& Widiastuti, M. (2013). Pengaruh konsep diri terhadap perilaku konsumtif mahasiswa
Universitas Esa Unggul. Jurnal Psikologi, 11(1), 50-65.

Harli, F.C., Linawati, N., \& Memarista. (2015). Pengaruf financial literacy \& factor sosio demografi terhadap perilaku konsumtif. FINESTA 3(1), 58-62.

Imawati, I., Susilaningsih, \& Ivada, E. (2013). Pengaruh financial literacy terhadap perilaku konsumtif remaja pada program IPS SMA Negeri 1 Surakarta tahun ajaran 2012/2013. Jupe UNS, 2(1). 48-58.

Januar, V., \& Putri, D.E. (2007). Citra tubuh pada remaja putri menikah dan memiliki anak. Jurnal Psikologi, $1(1), 52-62$.

Melliana, A.S. (2006). Menjelajah tubuh: perempuan dan mitos kecantikan. Yogyakarta: PT LKiS Pelangi Aksara.

Meza, L.D., \& Swinden, L. (2007). Body image. UK: David Gifford.

Murasmutia, A., Hardjajani, T., \& Adi, A. N. (2015). Correlation between body image and self confidence toward consumptive behaviour for clothes on the students at faculty of law UNS Surakarta. Jurnal Psikologi, 4(3), 206-218.

Nanu, C., Taut, D., \&Baban, A. (2014).Why adolescents are not happy with their body image. Journal of Gender and Feminist Studies. 2, 1-20.

National Eating Disorders Collaboration. (2005). Body Image. Diakses 15 September 2015 dari. http://www.nedc.com.au/files/logos/0 638_NEDC_FS_BI_v4.pdf.

Papalia, D.E., Olds, S.W., \& Feldman, R.D. (2008). Human development: psikologi perkembangan (ed.9.) (Alih bahasa: A. K. Anwar). Jakarta: Kencana Prenada Media Group.

Petova, S. S. (2012). Perilaku konsumtif pada pria metroseksual yang berpenghasilan pas-pasan. E-Jurnal Psikologi, 2, 1-47. Diakses dari http://publication.gunadarma.ac.id/bit stream/123456789/3519/1/JURNAL_ 2.pdf.

Ristia, A. (2014). Perbedaan citra tubuh antara remaja yang melakukan 
olahraga dan tidak melakukan olahraga di Kota Banda Aceh. Skripsi. Universitas Syiah Kuala, Banda Aceh.

Rombe, S. (2014). Hubungan body image dan kepercayaan diri dengan perilaku konsumtif pada remaja putri di SMA Negeri 5 Samarinda. Jurnal Psikologi, 2 (1), 76-91.

Santrock, J.W. (2007). Adolescence: perkembangan remaja. Jakarta: Erlangga.

Sari, S.H., \& Siregar, A.R. (2012). Peran body-image terhadap penyesuaian diri perempuan dewasa dini pada kehamilan pertama. Psikologiaonline, 7(2), 48-55.

Sari, T.Y. (2009). Hubungan antara perilaku konsumtif dengan body image pada remaja putri. Skripsi. Universitas Sumatera Utara, Medan.

Sebayang, S., Yusuf, M., \& Priyatama, A.N. (2011). Hubungan antara body image dan konformitas dengan perilaku konsumtif pada siswi kelas XI SMA Negeri 7 Surakarta. Jurnal Psikologi, 3(6). 5-41.

Stang, J., \& Story.(2005). Body image and adolescents chapter 13. Guidelines for adolescent nutrition services (pp. 155-157). Diakses dari http://www.epi.umn.edu/let/pubs/ado 1_book.shtm
Stuart, G. W., \& Laraia, M. T. (2005). Principle and practice of psychiatric nursing (Ed 8). St. Louis: Mosby.

Sugiyono.(2013). Metode penelitian kombinasi (mixed methodes). Bandung: Alfabeta.

Sumartono.(2002). Terperangkap dalam iklan. Bandung: Alfabeta.

Thompson, J. K., \&Smolak, L. (2001). Body image, eating disorders, and obesity in youth: Assessment, treatment and prevention (ed.2). Washington, DC: American Psychological Association.

Tylka, T. L., \& Barcalow, N. L. W. (2014). What is and what is not positive body image? Conceptual foundationsand construct definition. Journarl Body Image, 14 (2015), 118-129.

Wahyuni, P. (2013). Hubungan antara citra tubuh dengan harga diri pada remaja putri awal di Kecamatan Kuta Alam Banda Aceh. Skripsi. Universitas Syiah Kuala.

Waller, G., \& Barnes, J. (2002). Preconscious processing of body image cues: Impact on body percept and concept. Journal of Psychosomatic Research, 53, 10371041. 